\title{
GAMBARAN PROTEINURIA PADA IBU HAMIL TRIMESTER III DI RUMAH SAKIT KOTA PALEMBANG TAHUN 2019
}

\author{
Desty Mutiara Rezky ${ }^{1} \cdot$ Diah Navianti $^{*} \cdot$ Nurhayati $^{3}$ \\ ${ }^{1}$ Puskesmas Sosial, Dinkes Kota Palembang, Sumatera Selatan, Indonesia \\ ${ }^{2}$ Prodi D-III Kesehatan Lingkungan, Jurusan Kesehatan Lingkungan, Poltekkes Palembang, \\ Sumatera Selatan, Indonesia \\ ${ }^{3}$ Prodi D-III Analis Kesehatan, Jurusan Analis Kesehatan, Poltekkes Palembang, Sumatera \\ Selatan, Indonesia \\ e-Mail : diahnavianti@poltekkespalembang.ac.id
}

\begin{abstract}
Preeclampsia is a disorder in pregnancy. Preeclampsia is the presence of hypertension accompanied by oedema due to pregnancy and the most important sign is the presence of proteinuria. Proteinuria occurs later in the early pregnancy until it finally appears at the end of the trimester of pregnancy. This study was aimed to describe the proteinuria of third trimester pregnant women at Hospital Palembang in 2019 based on age, gravida status, occupation, history of hypertension and weight gain during pregnancy. It was a descriptive research with approach cross sectional. The research sample consisted of 65 third trimester pregnant women taken by accidental sampling technique. Proteinuria was examined with a dipstick method that is read with a verify U120 urine analyzer. The results showed $23.1 \%$ of samples were positive one and $7.7 \%$ positive two; A high percentage of protein in urine occurred in pregnant women based on risky age $<20$ atau $\geq 35(36,4 \%)$, based on gravida status in primigravida $(53,6 \%)$, based on occupation in house wife category $(37,5 \%)$, based on history of hypertension with there history of hypertension before pregnant (100\%), based on weight gain of obese category (50\%). It is recommended for pregnant women to do a complete urine examination every time they do a laboratory examination.
\end{abstract}

Keyword : Pregnant Women, Preeclampsia, Proteinuria

\begin{abstract}
Abstrak
Preeklampsia merupakan penyakit gangguan pada kehamilan. Preeklampsia adalah adanya hipertensi disertai dengan edema akibat kehamilan dan tanda yang paling penting adalah adanya proteinuria. Proteinuria timbul lebih lambat pada kehamilan awal hingga akhirnya mucul pada akhir trimester kehamilan. Penelitian ini bertujuan untuk mengetahui gambaran proteinuria pada ibu hamil trimester III di Rumah Sakit Palembang tahun 2019 berdasarkan umur, status gravida, status pekerjaan, riwayat penyakit hipertensi dan penambahan berat badan selama kehamilan. Penelitian ini bersifat Cross Sectional. Sampel penelitian sebanyak 65 orang ibu hamil trimester III yang diambil dengan teknik accidental sampling. Pemeriksaan proteinuria menggunakan metode carik celup yang dibaca dengan alat urine analyzer verify U120. Hasil penelitian ini menunjukkan sebanyak $23,1 \%$ positif satu dan $7,7 \%$ positif dua; Persentase terbesar adanya protein dalam urine terjadi pada ibu hamil berdasarkan umur ibu yang berisiko $<20$ atau $\geq 35$ tahun $(36,4 \%)$, berdasarkan status gravida pada primigravida $(53,6 \%)$, berdasarkan status pekerjaan pada kelompok IRT $(37,5 \%)$, berdasarkan riwayat penyakit dengan adanya riwayat penyakit sebelum kehamilan (100\%), berdasarkan penambahan berat badan pada kategori obesitas (50\%). Disarankan kepada ibu hamil untuk melakukan pemeriksaan urine lengkap setiap melakukan pemeriksaan laboratorium.
\end{abstract}

Kata Kunci : Ibu Hamil, Preeklampsia, Proteinuria

JolMedLabS. 2020;1(1):32-47

jurnal.aiptlmi-iasmlt.id | 32 


\section{PENDAHULUAN}

Kehamilan adalah masa dimana wanita membawa embrio dalam tubuhnya yang diawali dengan keluarnya sel telur yang matang pada saluran telur yang kemudian bertemu dengan sperma dan keduanya menyatu membentuk sel yang akan tumbuh dan membuat terjadinya proses konsepsi dan fertilisasi sampai lahirnya janin (Bandiya, 2014). Setiap kehamilan dapat berpotensi dan memiliki risiko bagi ibu yang disebut dengan Angka Kematian Ibu (AKI).

Angka Kematian Ibu (AKI) adalah jumlah kematian ibu selama masa kehamilan, persalinan dan atau dalam 42 hari sesudah berakhirnya kehamilan yang disebabkan oleh kehamilan, persalinan, nifas, tetapi bukan karena sebab-sebab lain seperti kecelakaan atau terjatuh di setiap 100.000 kelahiran hidup. Berdasarkan Survei Demografi dan Kesehatan Indonesia (SDKI) tahun 2012, angka kematian ibu di Indonesia masih tinggi yaitu 359 per 100.000 kelahiran hidup(Kementerian Kesehatan Republik Indonesia, 2014). Angka Kematian Ibu (AKI) di Sumatera Selatan masih tinggi, dilaporkan berdasarkan data Profil Kesehatan tahun 2015 yaitu 165 per 100.000 kelahiran hidu.(Dinas Kesehatan, 2015).

Penyebab kematian ibu dibagi menjadi dua yaitu penyebab langsung dan tidak langsung. Penyebab kematian ibu langsung antara lain akibat komplikasi kehamilan, persalinan, masa nifas, dan segala intervensi atau penanganan tidak tepat dari komplikasi tersebut. Sedangkan penyebab kematian ibu tidak langsung merupakan akibat dari penyakit yang sudah ada sebelum kehamilan atau penyakit yang timbul sewaktu kehamilan yang berpengaruh terhadap kehamilan (Prawirohardjo, 2010).

Secara global $80 \%$ kematian ibu tergolong pada kematian ibu langsung. Pola penyebab langsung di mana-mana sama, yaitu perdarahan (25\%), sepsis (15\%), hipertensi dalam kehamilan (12\%), parus macet (8\%), komplikasi aborsi (13\%), dan sebab-sebab lain (8\%). Eklampsia secara global terjadi pada 0,5\% 
kelahiran hidup dan 4,5\% hipertensi dalam kehamilan. Preeklampsia mempengaruhi banyak organ vital. Setelah terjadinya kejang atau pascakonvulsi pada eklampsia dapat menyebabkan kerusakan ginjal (Prawirohardjo, 2010).

Hipertensi dalam kehamilan merupakan 5 - $15 \%$ penyulit kehamilan dan merupakan salah satu dari tiga penyebab tertinggi mortalitas dan morbiditas ibu bersalin. Menurut Riskesdas, 2018 di Indonesia mortalitas dan morbiditas hipertensi dalam kehamilan juga masih cukup tinggi sebesar $3,8 \%$. Salah satu hipertensi dalam kehamilan adalah preeklampsia atau eclampsia (Prawirohardjo, 2010). Preeklampsia adalah sindrom spesifik-kehamilan berupa berkurangnya perfusi organ akibat vasospasme dan aktivasi endotel. Adapun preeklampsia dengan timbulnya hipertensi disertai dengan protein dalam urine yang meningkat dan edema akibat kehamilan setelah usia 20 minggu atau segera setelah melahirkan (Etika Desi Yogi, Hariyanto, 2014).

Proteinuria menunjukkan keadaan abnormal dimana jumlah protein dalam urine meningkat. Proteinuria merupakan tanda penting preeklampsi. Peningkatan tekanan dari darah yang masuk ke glomerulus dapat mengganggu filtrasi selektif glomerulus. Terjadinya proteinuria disebabkan oleh berkurangnya kapasitas tubulus ginjal mereabsorbsi protein yang telah difiltrasi, bertambahnya jumlah protein yang difiltrasi oleh glomerulus akibatnya tubulus tidak dapat mereabsobsi semua sehingga masih ada protein dalam cairan lumen tubulus dan dikeluarkan bersama urine, sekresi protein oleh sel-sel tubulus meningkat.

Proteinuria dibagi menjadi 3 kelompok berdasarkan konsentrasi protein dalam urine yaitu proteinuria hebat (ekskresi $>4 \mathrm{~g} /$ hari), proteinuria moderat atau sedang (ekskresi 0,5 - $4 \mathrm{~g} / \mathrm{hari}$ ), dan proteinuria ringan (ekskresi $<0,5$ $\mathrm{g} /$ hari). Pada tipe proteinuria moderat atau sedang ditemukan pada ibu hamil yang mengalami preeklampsia (Sinaga, 2011).

Preeklampsia ini umumnya terjadi pada trimester III kehamilan. Terdapat banyak risiko terjadinya hipertensi dalam kehamilan yang dapat 
menyebabkan terjadinya preeklampsia yaitu, umur ibu, usia kehamilan, status gravida (kehamilan keberapa), riwayat penyakit sebelum kehamilan seperti hipertensi dan penyakit ginjal, status pekerjaan, dan kenaikan berat badan (Dinas Kesehatan, 2015; Kandou et al., 2016; Lorenzo, 2016; Novianti, 2018).

Menurut hasil penelitian Inriani, 2014 didapatkan bahwa dari 12 orang ibu hamil umur $\leq 20$ tahun dan $\geq 35$ tahun yang positif proteinuria sebanyak 5 orang $(100 \%)$, dan dari 59 orang ibu hamil umur 21- 34 tahun tidak terdapat positif proteinuria.

Menurut hasil penelitan Rahmi dkk. (2016), menunjukkan hasil ibu dengan status primigravida mengalami pre-eklampsia sejumlah 8 ibu $(12,7 \%)$ sedangkan ibu dengan status multigravida mengalami pre-eklampsia sejumlah 4 ibu (2,5\%). Hasil analisis diperoleh $\mathrm{OR}=5,564$ berarti ibu dengan status primigravida berpeluang 5,564 kali mengalami pre-eklampsia dibandingkan dengan ibu dengan status multigravida.

Bedasarkan penelitian Kandou dkk. (2016) didapatkan bahwa ibu hamil berdasarkan status pekerjaan dimana hasil untuk penderita preeklampsia didominasi oleh kelompok pekerjaan IRT sebanyak 67 orang (84,8\%), pelajar sebanyak 3 orang $(3,79 \%)$, PNS sebanyak 6 orang $(7,59 \%)$ dan wiraswasta sebanyak 3 orang $(3,79 \%)$.

Menurut gizi kementerian kesehatan pertambahan berat badan pada ibu hamil yang dianjurkan adalah $10 \mathrm{~kg}-12,5 \mathrm{~kg}$. Berdasarkan penelitian Cedergren yang dikutip oleh Sa'adah (2013), didapatkan hasil penelitian penambahan berat badan ibu hamil yang terindikasi mengalami preeklampsia dengan kategori $<10 \mathrm{~kg}$ sebesar $8 \%$, kategori $10 \mathrm{~kg}-12,5 \mathrm{~kg}$ sebesar $10 \%$ dan $>12,5$ sebesar $29 \%$.

Berdasarkan penelitian Novianti (2018) menunjukkan hasil pemeriksaan protein pada ibu hamil Trimester III di Puskesmas Poasia Kota Kendari dengan hasil positif I sebanyak 6 orang (17,64\%) hasil positif II sebanyak 7 orang (20,59\%) dan hasil negatif sebanyak 21 orang $(61,77 \%)$.

Tujuan penelitian ini untuk mengetahui gambaran proteinuria pada ibu 
hamil trimester III di Rumah Sakit Umum Kota Palembang tahun 2019 berdasarkan umur, status gravida, status pekerjaan, riwayat penyakit hipertensi dan penambahan berat badan selama kehamilan.

\section{BAHAN DAN METODE}

Penelitian ini merupakan penelitian deskriptif dengan pendekatan cross sectional dimana pengukuran variabel dependen dan independen dilakukan sekaligus pada waktu yang bersamaan. Teknik sampling yang digunakan merupakan teknik accidental sampling yang dilakukan pada setiap ibu hamil yang datang untuk melakukan pemeriksaan laboratorium sampai jumlah sampel terpenuhi.

Populasi dalam penelitian ini adalah ibu hamil trimester III yang melakukan pemeriksaan laboratorium di laboratorium Rumah Sakit Kota Palembang Tahun 2019. Didapatkan jumlah sampel penelitian adalah ibu hamil trimester III yang diperiksa proteinuria di dalam laboratorium sebanyak 65 orang.

Spesimen yang diambil adalah urine. Metode yang digunakan dalam pemeriksaan protein urine adalah carik celup yang dibaca pada alat urine analyzer verify U120.

\section{HASIL}

Distribusi Frekuensi Proteinuria pada Ibu Hamil Trimester III di Rumah Sakit Kota Palembang Tahun 2019

Data yang digunakan untuk menggambarkan distribusi frekuensi Proteinuria pada ibu hamil di Rumah Sakit Kota Palembang. Dibawah ini adalah distribusi frekuensi proteinuria pada ibu hamil: 
Tabel 1 Distribusi Frekuensi Proteinuria pada Ibu Hamil Trimester III di Rumah Sakit Kota Palembang Tahun 2019

\begin{tabular}{ccc}
\hline Proteinuria & Jumlah & Persentase \\
\hline Negatif & 45 & $69,2 \%$ \\
Positif 1 & 15 & $23,1 \%$ \\
Positif 2 & 5 & $7,7 \%$ \\
\hline Total & 65 & $100 \%$ \\
\hline
\end{tabular}

Dari table 1.1 diketahui bahwa ibu hamil yang negatif proteinuria berjumlah 45 orang $(69,2 \%)$, positif 1 proteinuria berjumlah 15 orang $(23,1 \%)$ dan positif 2 proteinuria berjumlah 5 orang $(7,7 \%)$.

Distribusi Frekuensi Proteinuria pada Ibu Hamil Trimester III Berdasarkan Umur Ibu di Rumah Sakit Kota Palembang Tahun 2019

Distribusi frekuensi proteinuria pada ibu hamil berdasarkan umur ibu antara lain berisiko ( $<20$ atau $\geq 35$ tahun) dan tidak berisiko (20-34 tahun) dapat dilihat pada tabel berikut ini:

Tabel 2 Distribusi Frekuensi Proteinuria pada Ibu Hamil Trimester III Berdasarkan Umur Ibu di Rumah Sakit Kota Palembang Tahun 2019

\begin{tabular}{|c|c|c|c|c|c|c|}
\hline \multirow{3}{*}{ Umur Ibu } & \multicolumn{4}{|c|}{ Proteinuria } & \multirow{2}{*}{\multicolumn{2}{|c|}{ Jumlah }} \\
\hline & \multicolumn{2}{|c|}{ Negatif } & \multicolumn{2}{|c|}{ Positif } & & \\
\hline & $\mathrm{n}$ & $\%$ & $\mathrm{n}$ & $\%$ & $\mathbf{N}$ & $\%$ \\
\hline Berisiko & 7 & $63,6 \%$ & 4 & $36,4 \%$ & 11 & $100 \%$ \\
\hline Tidak Berisiko & 38 & $70,4 \%$ & 16 & $29,6 \%$ & 54 & $100 \%$ \\
\hline Total & 45 & $69,2 \%$ & 20 & $30,8 \%$ & 65 & $100 \%$ \\
\hline
\end{tabular}

Berdasarkan tabel 4.2 didapatkan hasil dari 65 orang ibu hamil pada 11 orang ibu hamil berisiko ( $<20$ atau $\geq 35$ tahun) yang diperiksa didapatkan hasil sebanyak 7 orang $(63,6 \%)$ negatif dan 4 orang $(36,4 \%)$ positif. Pada 54 orang ibu hamil tidak berisiko (20-34 tahun) yang diperiksa didapatkan hasil 
sebanyak 38 orang $(70,4 \%)$ negatif, 16 orang $(29,6 \%)$ positif protein dalam urine.

Distribusi Frekuensi Proteinuria pada Ibu Hamil Trimester III Berdasarkan Status Gravida di Rumah Sakit Kota Palembang Tahun 2019

Distribusi frekuensi proteinuria pada ibu hamil berdasarkan status gravida antara lain primigravida, secundugravida dan multigravida dapat dilihat pada tabel berikut ini:

Tabel 3 Distribusi Frekuensi Proteinuria Pada Ibu Hamil Berdasarkan Status Gravida di Rumah Sakit Kota Palembang Tahun 2019

\begin{tabular}{ccccccc}
\hline \multirow{2}{*}{ Status Gravida } & \multicolumn{4}{c}{ Proteinuria } & \multicolumn{2}{c}{ Jumlah } \\
\cline { 2 - 6 } & \multicolumn{2}{c}{ Negatif } & \multicolumn{2}{c}{ Positif } & \multicolumn{2}{c}{} \\
\cline { 2 - 6 } & $\mathbf{n}$ & $\%$ & $\mathbf{n}$ & $\%$ & $\mathbf{N}$ & $\%$ \\
\hline Primigravida & 13 & $46,4 \%$ & 15 & $53,6 \%$ & 28 & $100 \%$ \\
\hline Secundigravida & 23 & $85,2 \%$ & 4 & $14,8 \%$ & 27 & $100 \%$ \\
\hline Multigravida & 9 & $90 \%$ & 1 & $10,0 \%$ & 10 & $100 \%$ \\
\hline Total & 45 & $69,2 \%$ & 20 & $30,8 \%$ & 65 & $100 \%$ \\
\hline
\end{tabular}

Berdasarkan tabel 4.2 didapatkan hasil dari 65 orang ibu hamil pada 28 orang primigravida yang diperiksa didapatkan hasil sebanyak 13 orang $(46,4 \%)$ negatif dan 15 orang $(53,6 \%)$ positif protein dalam urine. Pada 27 orang secundigravida yang diperiksa didapatkan hasil sebanyak 23 orang $(85,2 \%)$ negatif dan 4 orang $(14,8 \%)$ positif protein dalam urine. Pada 10 orang multigravida yang diperiksa didapatkan hasil sebanyak 9 orang $(90 \%)$ negatif dan 1 orang (10\%) positif protein dalam urine.

Distribusi Frekuensi Proteinuria pada Ibu Hamil Trimester III Berdasarkan Status Pekerjaan di Rumah Sakit Kota Palembang Tahun 2019

Distribusi frekuensi proteinuria pada ibu hamil berdasarkan status pekerjaan antara lain ibu rumah tangga, pegawai negeri sipil (PNS), dan karyawan swasta dapat dilihat pada tabel berikut ini: 
Tabel 4 Distribusi Frekuensi Proteinuria pada Ibu Hamil Trimester III Berdasarkan Status Pekerjaan di Rumah Sakit Kota Palembang Tahun 2019

\begin{tabular}{ccccccc}
\hline Status Pekerjaan & \multicolumn{4}{c}{ Proteinuria } & \multicolumn{3}{c}{ Jumlah } \\
\cline { 2 - 5 } & \multicolumn{2}{c}{ Negatif } & \multicolumn{2}{c}{ Positif } & & \\
\cline { 2 - 6 } & $\mathrm{n}$ & $\%$ & $\mathrm{n}$ & $\%$ & $\mathrm{~N}$ & $\%$ \\
\hline Ibu Rumah Tangga & 20 & $62,5 \%$ & 12 & $37,5 \%$ & 32 & $100 \%$ \\
\hline PNS & 5 & $71,4 \%$ & 2 & $28,6 \%$ & 7 & $100 \%$ \\
\hline Karyawan Swasta & 20 & $76,9 \%$ & 6 & $23,1 \%$ & 26 & $100 \%$ \\
\hline Total & 45 & $69,2 \%$ & 20 & $30,8 \%$ & 65 & $100 \%$ \\
\hline
\end{tabular}

Berdasarkan tabel 4.4 didapatkan hasil dari 65 orang ibu hamil pada 32 orang sebagai ibu rumah tangga sebanyak 20 orang (62,5\%) negatif, dan 12 orang $(37,5 \%)$ positif proteinuria. Pada 7 orang ibu hamil yang pekerjaannya PNS sebanyak 5 orang $(71,4 \%)$ negatif dan 2 orang $(28,6 \%)$ positif proteinuria, dan pada 26 orang ibu hamil pekerjaannya karyawan swasta didapatkan hasil 20 orang $(76,9 \%)$ negatif dan 6 orang $(23,1 \%)$ positif protein dalam urine.

Distribusi Frekuensi Proteinuria pada Ibu Hamil Trimester III Berdasarkan Riwayat Penyakit di Rumah Sakit Kota Palembang Tahun 2019

Distribusi frekuensi proteinuria pada ibu hamil berdasarkan ada atau tidaknya riwayat penyakit seperti hipertensi antara lain dapat dilihat pada tabel berikut ini:

Tabel 5 Distribusi Frekuensi Proteinuria Pada Ibu Hamil Trimester III Berdasarkan Riwayat Penyakit di Rumah Sakit Kota Palembang Tahun 2019

\begin{tabular}{ccccccc}
\hline Riwayat Penyakit & \multicolumn{3}{c}{ Proteinuria } & \multicolumn{3}{c}{ Jumlah } \\
\cline { 2 - 6 } & \multicolumn{2}{c}{ Negatif } & \multicolumn{2}{c}{ Positif } & & \\
\cline { 2 - 6 } & $\mathbf{n}$ & $\%$ & $\mathbf{n}$ & $\%$ & $\mathbf{N}$ & $\%$ \\
\hline Ada & 0 & $0 \%$ & 5 & $100 \%$ & 5 & $100 \%$ \\
\hline Tidak Ada & 45 & $75 \%$ & 15 & $25 \%$ & 60 & $100 \%$ \\
\hline Total & 45 & $69,2 \%$ & 20 & $30,8 \%$ & 65 & $100 \%$ \\
\hline
\end{tabular}

Berdasarkan tabel 4.5 didapatkan hasil dari 65 orang ibu hamil ditemukan pada 5 orang yang mempunyai riwayat penyakit hipertensi sebelum 
kehamilan didapatkan hasil tidak ada yang negatif dan 5 orang (100\%) yang positif proteinuria dan pada 60 orang ibu hamil yang tidak mempunyai riwayat penyakit hipertensi sebelum kehamilan didapatkan hasil 45 orang (75\%) negatif dan 15 orang (25\%) positif protein dalam urine.

Distribusi Frekuensi Proteinuria Pada Ibu Hamil Trimester III Berdasarkan Penambahan Berat Badan di Rumah Sakit Kota Palembang Tahun 2019

Distribusi frekuensi proteinuria pada ibu hamil berdasarkan penambahan berat badan selama kehamilan antara lain kurang, normal, dan obesitas dapat dilihat pada tabel berikut ini:

Tabel 6 Distribusi Frekuensi Proteinuria pada Ibu Hamil Trimester III Berdasarkan Penambahan Berat Badan di Rumah Sakit Kota Palembang Tahun 2019

\begin{tabular}{ccccccc}
\hline \multirow{2}{*}{$\begin{array}{c}\text { Penambahan Berat } \\
\text { Badan }\end{array}$} & \multicolumn{3}{c}{ Negatif } & \multicolumn{2}{c}{ Positif } & \multicolumn{3}{c}{ Jumlah } \\
\cline { 2 - 6 } & $\mathbf{n}$ & $\%$ & $\mathbf{n}$ & $\%$ & $\mathbf{N}$ & $\%$ \\
\hline Normal & 29 & $87,9 \%$ & 4 & $12,1 \%$ & 33 & $100 \%$ \\
\hline Obesitas & 16 & $50 \%$ & 16 & $50 \%$ & 32 & $100 \%$ \\
\hline Total & 45 & $69,2 \%$ & 20 & $30,8 \%$ & 65 & $100 \%$ \\
\hline
\end{tabular}

Berdasarkan tabel 4.6 didapatkan hasil dari 65 orang ibu hamil tidak ditemukan ibu hamil yang penambahan berat badan selama kehamilan kategori kurang. Pada 33 orang yang penambahan berat badan selama kehamilan kategori normal didapatkan hasil 29 orang $(87,9 \%)$ negatif dan 4 orang $(12,1 \%)$ yang positif protein dalam urine. Pada 32 orang yang penambahan berat badan selama kehamilan kategori obesitas didapatkan hasil 16 orang (50\%) yang negatif dan 16 orang $(50 \%)$ yang positif.

\section{DISKUSI}

Gambaran Proteinuria pada Ibu Hamil Trimester III di Rumah Sakit Kota Palembang Tahun 2019

Penelitian ini dilakukan terhadap 65 orang di Rumah Sakit Kota 
Palembang menyimpulkan bahwa sebanyak 5 orang $(7,7 \%)$ ibu hamil positif dua protein dalam urine lebih sedikit dari pada ibu hamil yang positif satu sebanyak 15 orang $(23,1 \%)$ dan negatif protein dalam urine sebanyak 45 orang $(69,2 \%)$ pada ibu hamil trimester III.

Persentase hasil ini sejalan dengan penelitian Angelo $P$. Pangulimang,dkk, 2018 di Rumah Sakit Robert Wolter Mongisidi Manado dengan hasil yang positif 1 sebesar 20,51\% , positif 2 sebesar 2,57\% dan negatif proteinuria pada ibu hamil sebesar $76,92 \%$ dengan metode yang sama yaitu menggunakan cara carik celup dan pada sampel yang sama yaitu ibu hamil trimester III (Pangulimang et al., 2018).

Terjadinya proteinuria disebabkan oleh berkurangnya kapasitas tubulus ginjal mereabsorbsi protein yang telah difiltrasi, bertambahnya jumlah protein yang difiltrasi oleh glomerulus akibatnya tubulus tidak dapat mereabsobsi semua sehingga masih ada protein dalam cairan lumen tubulus dan dikeluarkan bersama urine (Sinaga, 2011). Adapun Keadaan sistem urologi dari ibu hamil trimester III akan merasakan ingin berkemih walaupun kandung kemih hanya berisi sedikit urine hal ini dikarenakan terjadinya pembesaran uterus yang menekan kandung kemih dan terjadi hemodilusi (terjadi puncak pengenceran darah) menyebabkan metabolisme air menjadi lancer (Novianti, 2018).

\section{Gambaran Proteinuria pada Ibu Hamil Trimester III Berdasarkan Umur Ibu di Rumah Sakit Kota Palembang Tahun 2019}

Penelitian ini dilakukan terhadap 65 orang ibu hamil pada 11 orang ibu hamil dengan umur berisiko ( $<20$ atau $\geq 35$ tahun) yang diperiksa didapatkan hasil sebanyak 7 orang $(63,6 \%)$ negatif dan 4 orang $(36,4 \%)$ positif proteinuria. Pada 54 orang ibu hamil berumur tidak berisiko (20-34 tahun) yang diperiksa didapatkan hasil sebanyak 38 orang $(70,4 \%)$ negatif dan 16 orang $(29,6 \%)$ positif protein dalam urine.

Hasil penelitian ini didapatkan umur berisiko yang negatif proteinuria 
lebih banyak dibandingkan yang positif hal ini dikarenakan menurut penelitian dari Sulistyaningsih dkk, menunjukkan bahwa sebagian besar ibu hamil memiliki tingkat pengetahuan tentang program perencanaan persalinan dan pencegahan komplikasi dalam kategori baik sebanyak 34,2\% dan cukup sebanyak 44,7\%. Hal ini menunjukkan bahwa ibu hamil telah memiliki pengetahuan tentang kehamilan yang didapatkan dari orang lain, buku yang dibaca atau media lainnya yang membagikan tentang kesehatan pada saat kehamilan dan ibu hamil yang sering melakukan Antenatal Care (Sulistyaningsih Prabawati, 2017).

Gambaran Proteinuria pada Ibu Hamil Trimester III Berdasarkan Status Gravida di Rumah Sakit Kota Palembang Tahun 2019

Penelitian ini dilakukan terhadap 65 orang ibu hamil. Pada 28 orang primigravida yang diperiksa didapatkan hasil sebanyak 13 orang $(46,4 \%)$ negatif dan 15 orang $(53,6 \%)$ positif proteinuria. Pada 27 orang secundigravida yang diperiksa didapatkan hasil sebanyak 23 orang $(85,2 \%)$ negatif dan 4 orang $(14,8 \%)$ positif proteinuria. Pada 10 orang multigravida didapatkan hasil sebanyak 9 orang $(90 \%)$ negatif dan 1 orang (10\%) positif proteinuria.

Penelitian ini sejalan dengan penelitian Rahmi dkk (2016), menunjukkan bahwa ibu dengan status primigravida mengalami preeklampsia sejumlah 8 ibu $(12,7 \%)$ sedangkan ibu dengan status multigravida mengalami pre-eklampsia sejumlah 4 ibu $(2,5 \%)$.

Secara teori, primigravida lebih berisiko untuk mengalami pre-eklampsia daripada multigravida. Hal ini terjadi karena pada primigravida mekanisme imunologik pembentukkan blocing antibody yang dilakukan oleh HLA-G (Human Leukocite Antigen $G$ ) terhadap antigen plasenta belum terbentuk secara sempurna, sehingga proses implantasi trofoblas ke jaringan desidual ibu menjadi terganggu. Primigravida juga rentan mengalami stress emosi yang menyebabkan peningkatan pelepasan Corticotropic-Releasing Hormone (CRH) oleh hipothalamus, yang kemudian menyebabkan peningkatan kortisol. Efek 
kortisol adalah mempersiapkan tubuh untuk berespons terhadap semua stressor dengan meningkatkan respons simpatis, termasuk respons yang ditujukan untuk meningkatkan curah jantung dan mempertahankan tekanan darah sehingga menyebabkan hipertensi.

Gambaran Proteinuria pada Ibu Hamil Trimester III Berdasarkan Status Pekerjaan di Rumah Sakit Kota Palembang Tahun 2019

Penelitian ini dilakukan terhadap 65 orang ibu hamil pada 32 orang sebagai ibu rumah tangga (IRT) didapatkan hasil 20 orang $(62,5 \%)$ negatif dan 12 orang $(37,5 \%)$ positif proteinuria. Pada 7 orang ibu hamil yang pekerjaannya PNS didapatkan hasil 5 orang $(71,4 \%)$ negatif dan 2 orang $(28,6 \%)$ positif proteinuria. Pada 26 orang ibu hamil yang pekerjaannya karyawan swasta didapatkan hasil 20 orang $(76,9 \%)$ negatif dan 6 orang $(23,1 \%)$ positif proteinuria.

Penelitian ini lebih rendah dari pada penelitian dari Rien A. Hutabarat, dkk, 2016 didapatkan bahwa ibu hamil berdasarkan status pekerjaan dimana hasil untuk penderita preeklampsia didominasi oleh kelompok pekerjaan IRT sebanyak 67 orang $(84,8 \%)$ (Kandou et al., 2016).

Preeklampsia didominasi oleh ibu hamil sebagai ibu rumah tangga dikarenakan aktivitas atau stres memikirkan masalah dalam rumah tangga, ekonomi, dan kecemasan menghadapi persalinan sehingga dapat mempengaruhi kerja otot dan peredaran darah. Kerja jantung akan semakin bertambah untuk memenuhi kebutuhan selama proses kehamilan sehingga menyebabkan hipertensi.

\section{Gambaran Proteinuria pada Ibu Hamil Trimester III Berdasarkan Riwayat} Penyakit di Rumah Sakit Kota Palembang Tahun 2019

Penelitian ini dilakukan terhadap 65 orang ibu hamil pada 5 orang yang mempunyai riwayat penyakit sebelum kehamilan didapatkan hasil tidak ditemukan yang negatif dan 5 orang (100\%) yang positif proteinuria. Pada 60 
orang ibu hamil yang tidak mempunyai riwayat penyakit sebelum kehamilan didapatkan hasil 45 orang (75\%) negatif dan 15 orang (25\%) positif proteinuria. Dan ibu hamil yang mempunyai riwayat penyakit sebelum kehamilan ini adalah adanya riwayat penyakit hipertensi.

Penelitian ini sejalan dengan penelitian Rahmawati Nina (2016), didapatkan $53,7 \%$ ibu hamil yang mempunyai riwayat penyakit sebelum kehamilan.

Adanya riwayat hipertensi sebelum kehamilan dapat menyebabkan terjadinya pre-eklampsia karena terjadinya gangguan pada organ penting dalam tubuh seperti adanya penurunan volume plasma, perfusi organ akibat vasospasme pembuluh darah dan aktivasi endotel kemudian ditambah dengan keadaan hamil yang membuat kerja di dalam tubuh akan semakin berat dan disertai dengan timbulnya edema dan proteinuria.

Gambaran Proteinuria pada Ibu Hamil Trimester III Berdasarkan Penambahan Berat Badan di Rumah Sakit Kota Palembang Tahun 2019

Penelitian ini dilakukan terhadap 65 orang ibu hamil pada 33 orang yang penambahan berat badan selama kehamilan kategori normal didapatkan hasil 29 orang $(87,9 \%)$ negatif dan 4 orang $(12,1 \%)$ positif proteinuria. Pada 32 orang yang penambahan berat badan selama kehamilan kategori obesitas didapatkan hasil 16 orang (50\%) negatif dan 16 orang (50\%) positif proteinuria.

Penelitian ini lebih rendah dibanding dengan hasil penelitian Sa'adah (2013) di RSUD dr. Moewardi Surakarta diperoleh dari 43 ibu hamil yang penambahan berat badan berlebih terdapat $27(62,7 \%)$ orang ibu hamil positif proteinuria.

Menurut penelitian Susanti Pratamaningtyas dkk. (2019), ibu hamil mengalami kenaikan berat badan yang tidak normal yaitu sebanyak 81 orang (89\%) dan sebagian kecil mempunyai kenaikan berat badan yang normal yaitu sebanyak 10 orang (11\%). Pertambahan berat badan selama kehamilan dapat dipengaruhi oleh beberapa faktor. Pertambahan berat badan didistribusikan 
antara janin, plasenta, membran, cairan amnion, dan perkembangan fisiologis organ-organ maternal, misalnya uterus dan payudara (deposisi darah dan lemak sebagai persiapan untuk laktasi).

Pada trimester III basal metabolik ibu hamil akan mengalami kenaikan, nafsu makan cukup baik dan biasanya ibu selalu merasa lapar. Hal ini dikarenakan pertumbuhan janin yang semakin pesat. Semakin membesarnya janin menyebabkan diafragma ibu mulai tertekan dan sulit makan dengan porsi yang besar (Novianti, 2018).

\section{KESIMPULAN}

Berdasarkan hasil penelitian mengenai Gambaran Proteinuria pada lbu Hamil Trimester III di Rumah Sakit Kota Palembang Tahun 2019 dapat disimpulkan distribusi frekuensi proteinuria pada ibu hamil didapatkan hasil peneliti sebanyak 15 orang $(23,1 \%)$ ibu hamil yang posititf 1 proteinuria, 5 orang $(7,7 \%)$ ibu hamil yang positif 2 proteinuria dan 45 orang $(69,2 \%)$ yang negatif proteinuria ibu hamil trimester III. Persentase terbesar adanya protein dalam urine terjadi pada ibu hamil berdasarkan umur ibu yang berisiko <20 atau $\geq 35$ tahun $(36,4 \%)$, berdasarkan status gravida pada primigravida $(53,6 \%)$, berdasarkan status pekerjaan pada kelompok IRT (37,5\%), berdasarkan riwayat penyakit dengan adanya riwayat penyakit sebelum kehamilan $(100 \%)$, berdasarkan penambahan berat badan pada kategori obesitas (50\%).

\section{UCAPAN TERIMAKASIH}

Terimakasih kepada Direktur Poltekkes Kemenkes Palembang, Ketua Jurusan

D-III Analis Kesehatan Poltekkes Palembang dan Rumah Sakit di Kota Palembang dan semua responden yang telah membantu saya dalam penelitian ini. 


\section{KONFLIK KEPENTINGAN}

Sebelum melakukan pemeriksaan kepada responden. Peneliti memberikan inform consent agar kerahasiaan identitas pasien tetap terjaga. Penelitian ini bersifat independent (tidak terikat) dengan institusi atau badan yang mendanai. Sehingga hasilnya objektif dan dapat dipertanggung jawabkan.

\section{REFRENSI}

Bandiya, S. (2014). Kehamilan Persalinan dan Gangguan Kehamilan. Nuha Medika.

Dinas Kesehatan. (2015). Profil Kesehatan Provinsi Sumatera Selatan. http://www.depkes.go.id/resources/download/profil/PROFIL_KES_PROVI NSI_2015/06_Sumsel_2015.pdf

Etika Desi Yogi, Hariyanto, E. S. (2014). Hubungan Antara Usia Dengan Preeklampsia Pada Ibu Hamil di POLI KIA RSUD Kefamenanu Kabupaten Tumor Tengah Utara. Delima Harapan, 3(2). https: / /doi.org/http://dx.doi.org/10.4236/ojo.2014.48035

Inriani. (2014). Gambaran Angka Kejadian Proteinuria Pada Ibu Hamil di Puskesmas Kassi-Makassar Tahun 2014. Universitas Islam Negeri Alauddin Makassar. https://doi.org/http://dx.doi.org/10.4236/ojo.2014.48035

Kandou, P. R. D., Hutabarat, R. A., Suparman, E., Wagey, F., Obstetri, B., Kedokteran, F., Sam, U., \& Manado, R. (2016). Karakteristik pasien dengan preeklampsia Kandidat Skripsi Fakultas Kedokteran Universitas Sam Ratulangi Manado. 4.

Kementerian Kesehatan Republik Indonesia. (2014). Infodatin Data and Information Center Ministry of Health Republic of Indonesia (Mother's dayAngka Kematian Ibu (AKI) adalah jumlah kematian ibu selama masa kehamilan, persalinan dan atau dalam 42 hari sesudah berakhirnya kehamilan yang disebabkan oleh keh (p. 8). http://www.depkes.go.id/resources/download/pusdatin/infodatin/infod atin-ibu.pdf

Lorenzo, S. K. S. \& M. S. Di. (2016). Urinalisis dan Cairan Tubuh (N. B. S. Dian Ramadhani (ed.); Edisi Ke 6). Buku Kedokteran EGC.

Novianti, R. (2018). Gambaran Hasil Pemeriksaan Protein Urine Pada Ibu Hamil Trimester III Di Puskesmas Poasia Kota Kendari. Poltekkes Kemenkes 
Kendari.

Pangulimang, A. P., Kaligis, S. H. M., \& Paruntu, M. E. (2018). Gambaran Kadar Protein Urin pada Ibu Hamil Trimester III di Rumah Sakit Robert Wolter Mongisidi Manado. Pangulimang, Kaligis, Paruntu, 6. https://ejournal.unsrat.ac.id/index.php/ebiomedik/article/download/22 $159 / 21860$

Prawirohardjo, S. (2010). Ilmu Kebidanan (Edisi ke 4). PT Bina Pustaka.

Rahmawati Nina. (2016). hubungan riwayat penyakit dengan kejadian preeklampsia pada ibu hamil RSUD panembahan senopati bantul yogyakarta. Keperawatan.

Rahmi, N., \& Djokosujono, K. (2016). Analisis Hubungan Usia, Status Gravida dan Usia Kehamilan dengan Pre- Eklampsia pada Ibu Hamil di Rumah Sakit Umum dr. Zaionel Abidin Provinsi Aceh Tahun Relationship Analysis of Age, Gravida Status and Age of Pregnancy with Pre- Eclampsia in Pregnant . 2(1), 99-109.

Sa'adah, N. (2013). Hubungan Antara Pertambahan Berat Badan Ibu Hamil Dengan Angka Kejadian Preeklampsia. Universitas Muhammadiyah Surakarta.

Sinaga, H. (2011). Urinalisis. Multi Sarana.

Sulistyaningsih Prabawati, V. I. (2017). Gambaran Pengetahuan Ibu Hamil Tentang Program Perencanaan Persalinan dan Pencegahan Komplikasi di Puskesmas Kalasan Sleman. 08(01), 80-88.

Susanti Pratamaningtyas, S. N. I. N., \& Kristianti, S. (2019). KEJADIAN PREEKLAMSIA DI RSUDGAMBIRAN KOTA KEDIRI so it can be concluded that there is a Relationship between Increasing Weight. 2(1). 